This Section of Epidemiology and Psychiatric Sciences appears in each issue of the Journal and is dedicated to all forms of creative production born of an intimate and individual urge, often secretive, unbound from the conventional art system rules. Through short descriptions of the Outsider art work of prominent artists and new protagonists often hosted in community mental health services, this Section intends to investigate the latest developments of the contemporary art scene, where the distances between the edge and the centre are becoming more and more vague.

Carole Tansella, Section Editor

\title{
Henry Darger and the Aronburg mystery
}

\section{Bonesteel*}

Independent, Chicago, UK
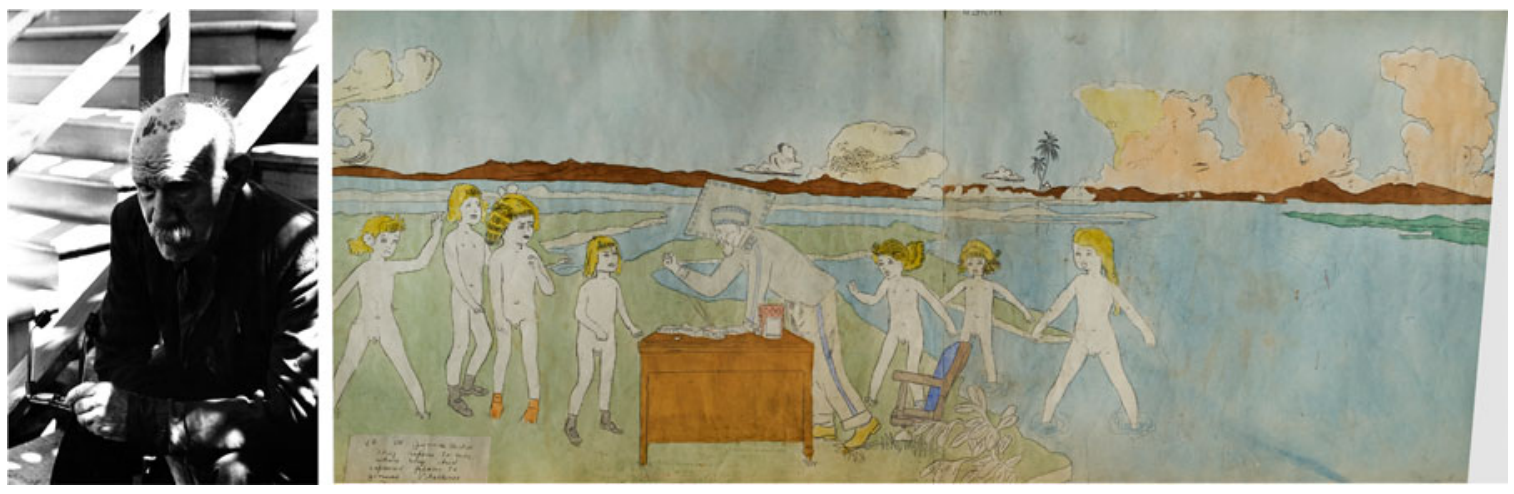

Henry Darger's artwork titled 'At Jennie Richee. They refuse to tell where they hid captured plans to general Phellinea Tamerline' (ca. 1940-1950) is by no means one of his most impressive compositions. In fact, compared with some of Darger's more extravagant later works, this piece is rather spare. But its aesthetic modesty belies its significance as the only known depiction of the villain Phellinea Tamerline in a scene with the Vivian girl princesses. ${ }^{1}$

\footnotetext{
* Address for correspondence: M. Bonesteel, Independent, Chicago, UK.

(Email: michaelbonesteel@yahoo.com)

${ }^{1}$ As the search for undocumented works by Henry Darger continues, other examples may yet come to light. But for now the only other image of Phellinea Tamerline known to exist is an early individual portrait that is part of a triptych titled 'Gen Ambrose Edwin Fuller...', ca, 1915-1930, carbon tracing, pencil and watercolor on
}

In addition to creating some 300 hundred carbontraced pencil and watercolor works of visual art, Darger (1892-1973) wrote an epic novel from 1910 to 1938 (MacGregor, 2002) titled 'In the Realms of the Unreal' $^{2}$ (hereafter simply referred to as the 'Realms') that served as the inspiration for his visual art. The saga takes place on an imaginary planet where a world war is waged over the enslavement of children by the Satanic Empire of Glandelinia. The young Christian heroines of Darger's tale are the seven

paper, mounted on cardboard_27 $\times 42.4 \mathrm{~cm}$, collection musée d'Art moderne de la Ville de Paris (Kazarian, 2015).

${ }^{2}$ The title of Darger's novel is 'In the Realms of the Unreal', although a longer, alternate title designated by Darger is: 'The Story of the Vivian Girls, in What is Known as the Realms of the Unreal, of the Glandeco-Angelinian War Storm, Caused by the Child Slave Rebellion'. 
intrepid Vivian sisters who have taken up the cause of the martyred leader of a child slave rebellion - a St. Joan of Arc-like character by the name of Annie Aronburg.

In the early years of writing his magnum opus, Darger created portraits for his characters by routinely cutting out photos from newspapers and magazines, then tracing and embellishing them according to his own designs. The original model for Annie Aronburg was the photograph of Elsie Paroubek, an abducted and murdered child taken from the front page of the Tuesday, 9 May 1911 edition of the Chicago Daily News (Bonesteel, 2000). Apparently, the photograph went missing before he had a chance to trace it. Darger blamed its loss on Thomas Phelan, a man he roomed with at St. Joseph's Hospital where he was employed.

Darger wrote in a journal entry: 'When first arrived sometime in 1910 Thomas Phelan a probably priest or hypocritical man caused loss of first manuscript either by failing to watch the place or by destroying it himself on the excuse of declaring it thrash (sic; i.e. trash) and refusing to own up what happened to it when asked.' A few sentences later, he claimed Phelan 'destroyed pictures of children along with Annie Aronburgs (sic)' that Darger had collected. ${ }^{3}$ Note that Darger identified Paroubek's picture as Annie Aronburg's, indicating the extent to which the boundary between reality and fiction had been compromised. Annie Aronburg's assassin in his novel assumed the name of General Thomas Phelan Tammerline, as well as variations such as Phellinea Tamerline.

Entering into his Realms saga as a fictional alter ego, General Hendro Dargar, the author/artist wrote: 'When the Child Labor Revolution broke out this little girl was elected a leader by the child rebels and, by her gallentry (sic) she made rapid progress which enraged Phelan who got permission from Federal (i.e. Glandelinian General Raymond Richardson Federal), to murder her in cold blood. I was the witness of the most bloodcurdlling (sic) crime ever committed in Calverinia. Annie Aronburg habited in her nighties had been probably occupying her mind for some time by planning for victory when the brute seized her by the hiar (sic) which was loose and flourished a razor about her face. The screams and struggles of the poor child had the effect of changing the probably guilty feeling of the rascal into those of wrath and instntly (sic) he began to chock (sic; i.e. choke) her tearing her nighties to tatters then with one determined sweep of his muscular arm he nearly severed her

\footnotetext{
${ }^{3}$ H Darger (ca. 1910-1930). Time Book Monthly, 'Prediction Cause of Demand for petition, Month of March 11, 1916', p. 27, collection of the American Folk Art Museum: New York, gift of Kiyoko Lerner, 2004.1.4.
}

chest open with his razor. The sight of blood incensed his anger into frenzy. Gashing (sic) his teeth and flashing fire from his eyes he flew upon the body of the unconscous (sic) child and imbedded (sic) his fearful tarlons (sic; i.e. talons) in her throat retaining his grasp untill (sic) she expired.' ${ }^{4}$

This situation assumed monumental proportions when Darger, a devout Catholic, prayed in vain to God for the photo's return, and then created a parallel event in the Realms in which a picture of Annie Aronburg disappears. Darger referred to it in the Realms and in his journal as 'the Aronburg mystery'.

He began to threaten God both in his journal and novel that if the missing photo did not turn up, he would turn the tide of the war in the Realms against the Christians and in favour of the Glandelinians. As the years turned into decades, he prolonged the war and the carnage in the hope that God would somehow relent and manifest the missing photo. 5 There is a good reason to suspect that the irresolution of the Aronburg mystery is the reason for the Realms unprecedented length: At more than 15000 pages, it is thought to be the longest work of fiction ever written.

\section{References}

Bonesteel M (2000). Henry Darger: Art and Selected Writings. Rizzoli International Publications: New York.

Kazarian C (2015). Henry Darger 1892-1873. Musee d'Art moderne de la Ville de Paris: Paris.

MacGregor JM (2002). Henry Darger: In the Realms of the Unreal. Delano Greenidge Editions: New York.

\section{About the author}

Michael Bonesteel is an independent writer, curator, contributing editor to the Raw Vision magazine and author of 'Henry Darger: Art and Selected Writings' (Rizzoli, 2000). He was formerly an adjunct professor at the School of the Art Institute of Chicago, art critic for the Art in America and managing editor of the New Art Examiner.

\section{Carole Tansella, Section Editor}

\footnotetext{
${ }^{4}$ H Darger (ca. 1910-1930). 'The Story of the Vivian Girls, in What Is Known as the Realms of the Unreal, of the Glandeco-Angelinian War Storm, Caused by the Child Slave Rebellion', unpublished manuscript, Volume VII, unbound, pp. 3/side a-3/side b, 1913 (before 1928), collection American Folk Art Museum, New York, gift of Kiyoko Lerner, 2004.1.4.

${ }^{5}$ Darger ultimately traced a photo of child actor Shirley Temple for his portrait of 'Annabelle Aronburg Vivian' ca. 1915-1930, carbon tracing, pencil and watercolor, $6.7 \times 5.5 \mathrm{~cm}$.
} 